Vol. 11 (2002): 285-300.

\title{
Arsenic and heavy metal concentrations in agricultural soils in South Savo province
}

Väinö Mäntylahti and Pirkko Laakso

Viljavuuspalvelu Oy, PO Box 500, FIN-50101 Mikkeli, Finland,

e-mail:vaino.mantylahti@viljavuuspalvelu.fi

\begin{abstract}
Increasing concentrations of arsenic and heavy metals in agricultural soils are becoming a growing problem in industrialized countries. These harmful elements represent the basis of a range of problems in the food chain, and are a potential hazard for animal and human health. It is therefore important to gauge their absolute and relative concentrations in soils that are used for crop production. In this study the arsenic and heavy metal concentrations in 274 mineral soil samples and 38 organogenic soil samples taken from South Savo province in 2000 were determined using the aqua regia extraction technique. The soil samples were collected from 23 farms. The elements analyzed were arsenic, cadmium, chromium, copper, mercury, nickel, lead and zinc. The median concentrations in the mineral soils were: As $2.90 \mathrm{mg} \mathrm{kg}^{-1}$, Cd $0.084 \mathrm{mg} \mathrm{kg}^{-1}$, Cr $17.0 \mathrm{mg} \mathrm{kg}^{-1}, \mathrm{Cu} 13.0 \mathrm{mg} \mathrm{kg}^{-1}, \mathrm{Hg} 0.060 \mathrm{mg}$ $\mathrm{kg}^{-1}$, Ni $5.4 \mathrm{mg} \mathrm{kg}^{-1}$, $\mathrm{Pb} 7.7 \mathrm{mg} \mathrm{kg}^{-1}$, Zn $36.5 \mathrm{mg} \mathrm{kg}^{-1}$. The corresponding values in the organogenic soils were: As $2.80 \mathrm{mg} \mathrm{kg}^{-1}$, Cd $0.265 \mathrm{mg} \mathrm{kg}^{-1}$, Cr $15.0 \mathrm{mg} \mathrm{kg}^{-1}$, Cu $29.0 \mathrm{mg} \mathrm{kg}^{-1}, \mathrm{Hg} 0.200 \mathrm{mg} \mathrm{kg}^{-1}$, Ni $5.9 \mathrm{mg} \mathrm{kg}^{-1}, \mathrm{~Pb} 11.0 \mathrm{mg} \mathrm{kg}^{-1}$, Zn $25.5 \mathrm{mg} \mathrm{kg}^{-1}$. The results indicated that cadmium and mercury concentrations in the mineral and organogenic soils differed. Some of the arsenic, cadmium and mercury concentrations exceeded the normative values but did not exceed limit values. Most of the agricultural fields in South Savo province contained only small amounts of arsenic and heavy metals and could be classified as "Clean Soil". A draft for the target values of arsenic and heavy metal concentrations in "Clean Soil" is presented.
\end{abstract}

Key words: arsenic, heavy metals, soil, classification, normative and limit values, soil pollution, Finland

\section{Introduction}

The concentration of an element in soil is the end result of its input and output from different sources. The input includes the sources of the parent material, atmospheric deposition, fertiliz- ers, agrochemicals, organic wastes and inorganic pollutants. The output includes removal in harvested crops, leaching and volatilization. Thus the concentration of a soil trace element can increase, e.g. cadmium and copper, or decrease, e.g. lead in Finnish and Swedish soils (Sippola and Mäkelä-Kurtto 1993, Eriksson et 
Mäntylahti, V. \& Laakso, P. Arsenic and heavy metal concentrations in agricultural soils

al. 1997, Tarvainen and Kuusisto 1999). Agrochemicals and farmyard manure apparently represent the main sources of the increasing concentrations of cadmium and copper in topsoils (Eriksson et al. 1997, Mäkelä-Kurtto 1998, Tarvainen and Kuusisto 1999).

Soil digestion with strong mineral acids is considered a form of pseudo-total analysis. Mineral acids (e.g. $\mathrm{HCl}, \mathrm{H}_{2} \mathrm{SO}_{4}, \mathrm{HNO}_{3}$ ) do not completely dissolve silicates (Ure 1990, Salminen 1995), but are strong enough to dissolve the heavy metals not bound to silicate phases, which is the normal case for most heavy metal pollutants (Ure 1990).

Guideline, normative, limit and target values have been designated for the concentrations of heavy metals and arsenic. The analyses are based on aqua regia - extractable quantities of the elements. The normative value expresses the maximum concentration of the harmful element considered harmless to man and the environment. The limit value expresses the concentration of the harmful element that requires cleaning processes. The target values are used to describe the national limits for different soils (Directive 86/ 278/EEC). Accordingly, guidelines for the target values vary depending on the issuing authority. These are based on the concentrations of the elements in natural soils and on soil parameters. For example, the Dutch national target values to limit pollution from sewage sludge applied to agricultural land are based on soil texture, clay content and organic matter content (Smit 1997). The Finnish Ministry of the Environment follows the same rules, but applies smaller constants to calculate target values (Ympäristöministeriö 2000). Soil is considered to be clean when it contains arsenic and heavy metals at concentrations lower than the target values (Viljavuuspalvelu 2000).

Finnish geological, forest and agrochemical surveys have provided basic data on the heavy metal concentrations in forest and cultivated soils based on dissolution in aqua regia. The soil maps cover the entire country at a density of $<1-$ 10 samples per $1000 \mathrm{~km}^{-2}$ (Tarvainen 1996). However, the studies differ in the selection of the elements analyzed, in the sampling depth, and in the particle size fraction of the samples (Sippola and Mäkelä-Kurtto 1986, 1993, Salminen 1995, Salminen and Lampio 1995, Tarvainen and Kallio 1999, Tarvainen and Kuusisto 1999). The particle size fraction in particular has an effect on the concentrations of trace elements (Tarvainen 1995) and therefore care should be taken when making comparisons. Trace element concentrations in Finland range from very low values $[<$ the limit of quantification, e.g. arsenic (As), cadmium (Cd), cobalt (Co), chromium $(\mathrm{Cr})$, copper $(\mathrm{Cu})$, nickel $(\mathrm{Ni})$, lead $(\mathrm{Pb})$, zinc $(\mathrm{Zn})]$ to levels above the normative or limit values, e.g. As, Cr, Ni (Sippola and Mäkelä-Kurtto 1986, 1993, Tamminen and Starr 1990, Nenonen and Nikkarinen 1995, Tarvainen and Kallio 1999, Tarvainen and Kuusisto 1999, Lahdenperä et al. 2001, Nykänen-Kurki et al. 2001). In the other Nordic Countries, trace element concentrations seem to follow the same trends as in Finland (e.g. Jeng and Bergseth 1992, Eriksson et al. 1997) although differences in analytical techniques make direct comparison difficult.

The aim of this work was to study variation in the arsenic and heavy metal concentrations in cultivated soils of South Savo province in Finland. The results were compared with the normative and limit values. The possibilities of identifying soils with low arsenic and heavy metal concentrations for plant production, and to hallmark these soils, were also investigated.

\section{Material and methods}

\section{Study material}

The project was carried out in the province of South Savo in eastern Finland (Fig. 1). Soil samples were collected from farms engaged in plant, herb, vegetable and animal production. The selection of farms was made by the local agricultural advisory organization, the Mikkeli Rural Advisory Centre. The farms were relatively 
Vol. 11 (2002): 285-300.

Fig. 1. The location of the study farms in South Savo Province.

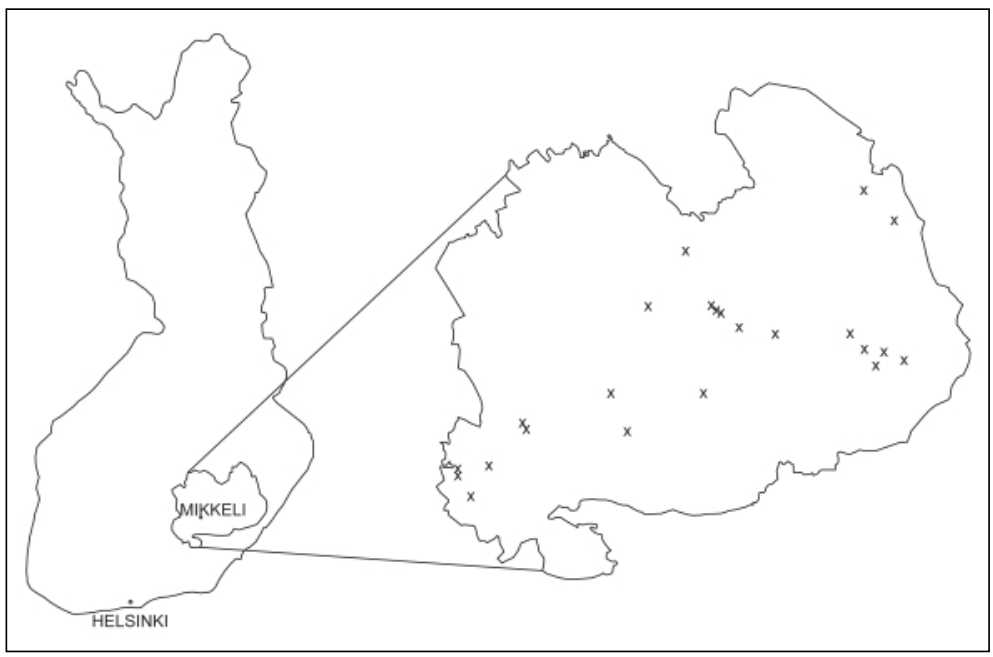

evenly spread throughout South Savo province (Fig. 1) and no heavy metal emission sources were identified near the farms. Traffic in the vicinity of the selected farms was less than near major roads. The average field area of the farms was 25 ha, and ranged from 3 to 80 ha. The size of the farms in terms of cultivated area was slightly less than the Finnish average (27.8 ha in 2000, http://matilda.mmm.fi/).

\section{Soil sampling}

The extension staff of Mikkeli Rural Advisory Centre collected the soil samples from 23 farms in autumn 2000. One to 35 soil samples (mean 13.5) were taken per farm. The number of samples taken for soil fertility testing was approximately the same that normally collected, resulting in an average of 0.6 samples per ha. The number of samples per farm and additional information are presented in Table 1.

The samples were collected from the plough layer, and consisted of 6-8 sub-samples, representing an area of about $100 \mathrm{~m}^{2}$. The depth of the plough layer was from $15 \mathrm{~cm}$ to $25 \mathrm{~cm}$. The sample size was about 0.4 litre.

\section{Analytical methods}

\section{Basic methods}

The soil samples were air dried at $40^{\circ} \mathrm{C}$, ground and homogenized ( $<2 \mathrm{~mm}$ sieve) with an Alpine Multi-Purpose Mill 25 MZ before analysis. Soil texture was determined using the pipette method of Elonen (1971) before the samples were ground. The wet digestion method was used to determine the organic matter content (Graham 1948). The material was classified into soil groups according to Aaltonen et al. (1949) (Table 2). Most of the soil samples were classified as coarse-textured mineral and till soils. This distribution was typical of South Savo province (Kähäri et al. 1987).

The soil samples were characterized using the soil fertility testing method widely used in Finland (soil $\mathrm{pH}_{\mathrm{H} 2 \mathrm{O}} 1: 2.5 \mathrm{v} / \mathrm{v}, \mathrm{Ca}, \mathrm{K}, \mathrm{P}$ and $\mathrm{Mg}$ extracted with $0.5 \mathrm{M} \mathrm{CH}_{3} \mathrm{COONH}_{4}, 0.5 \mathrm{M}$ $\mathrm{CH}_{3} \mathrm{COOH}, \mathrm{pH} 4.65,1: 10 \mathrm{v} / \mathrm{v}, 1 \mathrm{~h}$, Vuorinen and Mäkitie 1955; $\mathrm{Cu}, \mathrm{Zn}$ and $\mathrm{Mn}$ extracted with $0.5 \mathrm{M} \mathrm{CH}_{3} \mathrm{COONH}_{4}, 0.5 \mathrm{M} \mathrm{CH}_{3} \mathrm{COOH}, 0.02 \mathrm{M}$ $\mathrm{Na}_{2}$ EDTA, pH 4.65, 1:10 v/v, 1h, Lakanen and Erviö 1971, Mohammadi et al. 1991), Table 3. According to the soil testing analyses, soil $\mathrm{pH}_{\mathrm{H}_{2} \mathrm{O}}$ and the $\mathrm{Ca}, \mathrm{K}, \mathrm{P}$ and $\mathrm{Mg}$ concentrations were in most cases higher than the average values for cultivated soils in Mikkeli province (un- 
Mäntylahti, V. \& Laakso, P. Arsenic and heavy metal concentrations in agricultural soils

Table 1. Details and origin of soil samples taken from farms in South Savo province, Finland, in 2000.

\begin{tabular}{|c|c|c|c|c|}
\hline $\begin{array}{l}\text { Farm } \\
\text { number }\end{array}$ & $\begin{array}{c}\text { Farm size } \\
\text { ha }\end{array}$ & $\begin{array}{c}\text { Number of } \\
\text { samples }\end{array}$ & $\begin{array}{c}\text { Samples } \\
\text { per ha }\end{array}$ & Main production \\
\hline 13 & $*)$ & 1 & $*)$ & Herb production \\
\hline 12 & 3.0 & 1 & 0.3 & Vegetable production \\
\hline 22 & 14.5 & 7 & 0.5 & Animal production \\
\hline 11 & 13.3 & 7 & 0.5 & Plant production \\
\hline 19 & 5.2 & 7 & 1.3 & Plant production \\
\hline 18 & 20.8 & 10 & 0.5 & Animal production \\
\hline 7 & 12.0 & 11 & 0.9 & Plant production \\
\hline 4 & 34.0 & 12 & 0.4 & Animal production \\
\hline 23 & 15.0 & 12 & 0.8 & $*)$ \\
\hline 2 & 49.0 & 13 & 0.3 & Vegetable production \\
\hline 1 & 13.4 & 13 & 1.0 & Animal production \\
\hline 5 & 11.8 & 13 & 1.1 & Plant production \\
\hline 3 & 36.0 & 14 & 0.4 & Animal production \\
\hline 15 & 21.1 & 14 & 0.7 & Animal production \\
\hline 17 & 18.3 & 14 & 0.8 & Animal production \\
\hline 9 & 25.0 & 15 & 0.6 & Animal production \\
\hline 16 & 17.7 & 16 & 0.9 & Plant production \\
\hline 20 & 23.5 & 17 & 0.7 & Animal production \\
\hline 8 & 34.0 & 19 & 0.6 & Animal production \\
\hline 10 & 29.4 & 19 & 0.6 & Animal production \\
\hline 6 & 22.3 & 20 & 0.9 & Vegetable production \\
\hline 14 & 46.6 & 22 & 0.5 & Animal production \\
\hline 21 & 80.6 & 35 & 0.4 & Animal production \\
\hline
\end{tabular}

*) Unknown

Table 2. Distribution of the soil samples taken from farms in South Savo province, Finland, in 2000 according to soil texture group. Means and standard deviations (in parentheses) are given.

\begin{tabular}{|c|c|c|c|c|}
\hline \multirow[t]{2}{*}{ Soil texture group } & \multirow{2}{*}{$\begin{array}{c}\text { Number of } \\
\text { samples }\end{array}$} & \multicolumn{2}{|c|}{ Size fraction } & \multirow{2}{*}{$\begin{array}{c}\text { Organic } \\
\text { Matter, \% }\end{array}$} \\
\hline & & $<2 \mu \mathrm{m}, \%$ & $2-20 \mu \mathrm{m}, \%$ & \\
\hline \multicolumn{5}{|l|}{ Clay soils } \\
\hline Silty clay & 2 & $33(3.5)$ & $49(3.5)$ & $4.4(1.1)$ \\
\hline Clay loam & 1 & 32 & 42 & 11.8 \\
\hline \multicolumn{5}{|c|}{ Coarse-textured mineral soils } \\
\hline Silt & 1 & 8 & 53 & 9.8 \\
\hline Loam & 3 & $24(3.6)$ & $36(9.8)$ & $8.0 \quad(3.6)$ \\
\hline Very fine sand & 10 & $6.0(5.1)$ & $24(9.2)$ & $8.4 \quad(5.9)$ \\
\hline Medium fine sand & 136 & $3.5(2.5)$ & $12(4.5)$ & $6.7 \quad(3.6)$ \\
\hline Medium coarse sand & 32 & $2.8(1.9)$ & $10(5.4)$ & $9.2 \quad(4.7)$ \\
\hline \multicolumn{5}{|l|}{ Till } \\
\hline Fine sandy till & 68 & $3.2(2.4)$ & $12(3.3)$ & $6.4 \quad(3.1)$ \\
\hline Sandy till & 21 & $1.7(1.6)$ & $8.0(2.9)$ & $4.4(0.96)$ \\
\hline \multicolumn{5}{|l|}{ Organogenic soils } \\
\hline Mull & 24 & & & $27 \quad(5.3)$ \\
\hline Well-decomposed peat & 14 & & & $58 \quad(11)$ \\
\hline
\end{tabular}


Vol. 11 (2002): 285-300.

published data). However, the EDTA-extractable $\mathrm{Cu}$ and $\mathrm{Zn}$ concentrations were mostly relatively lower than the average values for Mikkeli province (unpublished data). The EDTA-extractable $\mathrm{Mn}$ concentration ( $\mathrm{mg} \mathrm{l}^{-1}$ ) was converted into $\mathrm{Mn}$-values using the $\mathrm{pH}$-value (Mohammadi et al. 1991), and, based on this manipulation, the results were expressed without a quality unit (Table 3). Bulk density was determined by weighing $25 \mathrm{ml}$ of air-dried, ground soil and thus corresponded to the bulk density of disturbed soil (Table 3).

The results of soil analyses are usually presented as w/w values, i.e. weight per unit weight. This method is used, for example, in ISO 11047. However, the results of soil analyses can be calculated as w/v, weight per unit volume (e.g. Vuorinen and Mäkitie 1955). The rationale is that plant roots have the same soil volume for growth independent of the bulk density of the soil. This is especially relevant when the results for mineral soils are compared with those for organogenic soils. This study material also comprised mull and peat soils. The bulk density of the mineral soils ranged from 0.65 to $1.36 \mathrm{~kg} \mathrm{dm}^{-3}$, and in the organogenic soils from 0.32 to $0.78 \mathrm{~kg}$ $\mathrm{dm}^{-3}$ (Table 3). The results were accordingly also calculated as $\mathrm{w} / \mathrm{v}$.

\section{Methods for analysis of arsenic and heavy metals}

The pre-treatment of the samples (drying and crushing) was performed by Soil Analysis Service Ltd according to the ISO 11464 method. The analyses were carried out either in the laboratory of Soil Analysis Service Ltd, Mikkeli, or in the laboratory of the Geological Survey of Finland, Kuopio. Both of the laboratories used a slightly modified form of the ISO 11466 method. The method is based on aqua regia digestion ( $1 \mathrm{~g}$ soil, $7.5 \mathrm{ml}$ conc. $\mathrm{HNO}_{3}, 2.5 \mathrm{ml}$ conc. $\mathrm{HCl}$, $12 \mathrm{~h}$ pause, $2 \mathrm{~h}$ digestion, filtering with $\mathrm{S} \& \mathrm{~S}$ $589^{2}$ ). The analyses were performed as described in Table 4. Each soil batch (about 20 samples) sent to the Geological Survey of Finland included an internal control sample from Soil Analysis Service Ltd, and an average of every tenth sample was duplicated. Based on the results of the control samples, the arsenic results were multiplied by a factor of 1.5 , the mercury results by a factor of 1.6 and the lead results by a factor of 1.3. The results were calculated as $\mathrm{mg} \mathrm{kg}^{-1}$ on a dry matter basis.

Copper and zinc are plant nutrients, but are also classified as heavy metals. In this study the EDTA-extraction was used to characterize soil material (Table 3), but the aqua regia digestion was used for evaluating copper and zinc concentrations for environmental purposes.

\section{Statistical methods}

In this study the limit of quantification was used as the result for the sample without manipulation when the element concentration fell below it. This method limited the use of the various parameters to characterize the data. However, the data are presented together with the statistical parameters, including the mean, median, standard deviation and range. The skewness was defined as the quotient of the third moment about the mean and the third power of the standard deviation. In accordance with ASTM (1997), the averages were reported to one more decimal place than the original data that were found to be significant. The percentiles were also calculated. None of the results were discarded.

The untransformed data indicated positive skewness and, as a result, the statistical parameters such as the mean and the median differed from each other. This problem has been reported previously and the data have been transformed in many reports (e.g. Berrow and Reaves 1984). The method decreases the weight of the high values while retaining the problems of low values ( $<$ the limit of quantification). However, in this material no very high values were obtained in comparison with the results of Berrow and Reaves (1984) and Jeng and Bergseth (1992), and therefore the data were not transformed.

In order to evaluate the element concentrations in agricultural soil in South Savo province, the results were classified on the basis of their 
Mäntylahti, V. \& Laakso, P. Arsenic and heavy metal concentrations in agricultural soils

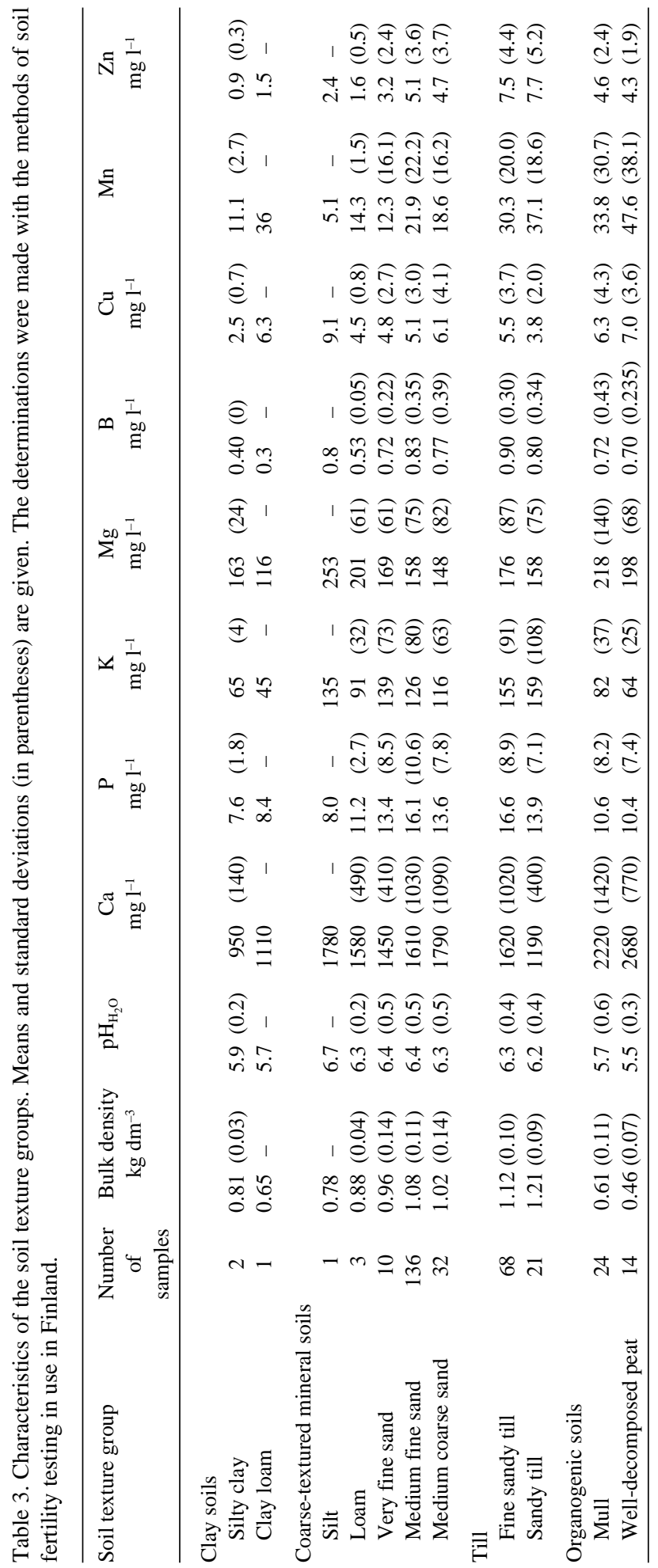


Vol. 11 (2002): 285-300.

Table 4. Analytical techniques and uncertainty for the arsenic and heavy metal analyses.

\begin{tabular}{lccc}
\hline Element & Soil Analysis Service Ltd & Geological Survey of Finland & $\begin{array}{c}\text { Expanded uncertainty at } \\
9 \% \text { confidence level, } \%\end{array}$ \\
\hline Arsenic & GF-AAS & GF-AAS & n.e. \\
Cadmium & GF-AAS & GF-AAS & 35 \\
Chromium & ICP-AES & ICP-AES & 20 \\
Copper & ICP-AES & ICP-AES & n.e. \\
Mercury & FIA-AAS & Flameless AAS & 40 \\
Nickel & ICP-AES & ICP-AES & n.e. \\
Lead & ICP-AES & ICP-AES & 45 \\
Zinc & ICP-AES & ICP-AES & n.e. \\
\hline
\end{tabular}

GF-AAS = graphite furnace-atomic absorption spectrometry

ICP-AES = inductively coupled plasma-atomic emission spectrometry

FIA-AAS = flow injection analysis-atomic absorption spectrometry

Flameless AAS = flameless-atomic absorption spectrometry

n.e. $=$ not estimated

distribution. Sillanpää (1982) divided his results into five groups depending on the percentiles of the material as follows: $5 \%, 10 \%, 70 \%, 10 \%$ and $5 \%$. A slight modification of this method was used in this study. The mean and standard deviation were calculated. The mean plus a single standard deviation was used to calculate the values for different elements. The samples that fell below this value were termed "Clean Soils". This level was used to indicate the trace element concentrations in South Savo province compared with the results from other studies. The limits were compared, for example, with the limits pro- posed by Soil Analysis Service (Viljavuuspalvelu 2000).

\section{Results and discussion}

\section{Arsenic and heavy metal concentrations}

A high proportion of the results for nickel, mercury, cadmium, copper and arsenic fell below the limit of quantification (Table 5). The low values

Table 5. The number of soil samples falling below the limit of quantification (< LOQ) and equal to the limit of quantification (= LOQ) for arsenic and heavy metals.

\begin{tabular}{|c|c|c|c|c|c|}
\hline \multirow[t]{2}{*}{ Element } & \multirow{2}{*}{$\begin{array}{c}\text { Limit of } \\
\text { quantification } \\
\mathrm{mg} \mathrm{kg}^{-1}\end{array}$} & \multicolumn{2}{|c|}{ Mineral soils } & \multicolumn{2}{|c|}{ Organogenic soils } \\
\hline & & $<\mathrm{LOQ}$ & $=\mathrm{LOQ}$ & $<\mathrm{LOQ}$ & $=\mathrm{LOQ}$ \\
\hline Arsenic & 1 & 6 & 1 & - & 2 \\
\hline Cadmium & 0.05 & 37 & 13 & - & 1 \\
\hline Chromium & 0.1 & - & - & - & - \\
\hline Copper & 5 & 12 & - & - & - \\
\hline Mercury & 0.05 & 75 & 22 & - & - \\
\hline Nickel & 5 & 103 & 5 & 12 & - \\
\hline Lead & 2.0 & - & - & - & - \\
\hline Zinc & 10 & - & - & - & - \\
\hline
\end{tabular}


Mäntylahti, V. \& Laakso, P. Arsenic and heavy metal concentrations in agricultural soils

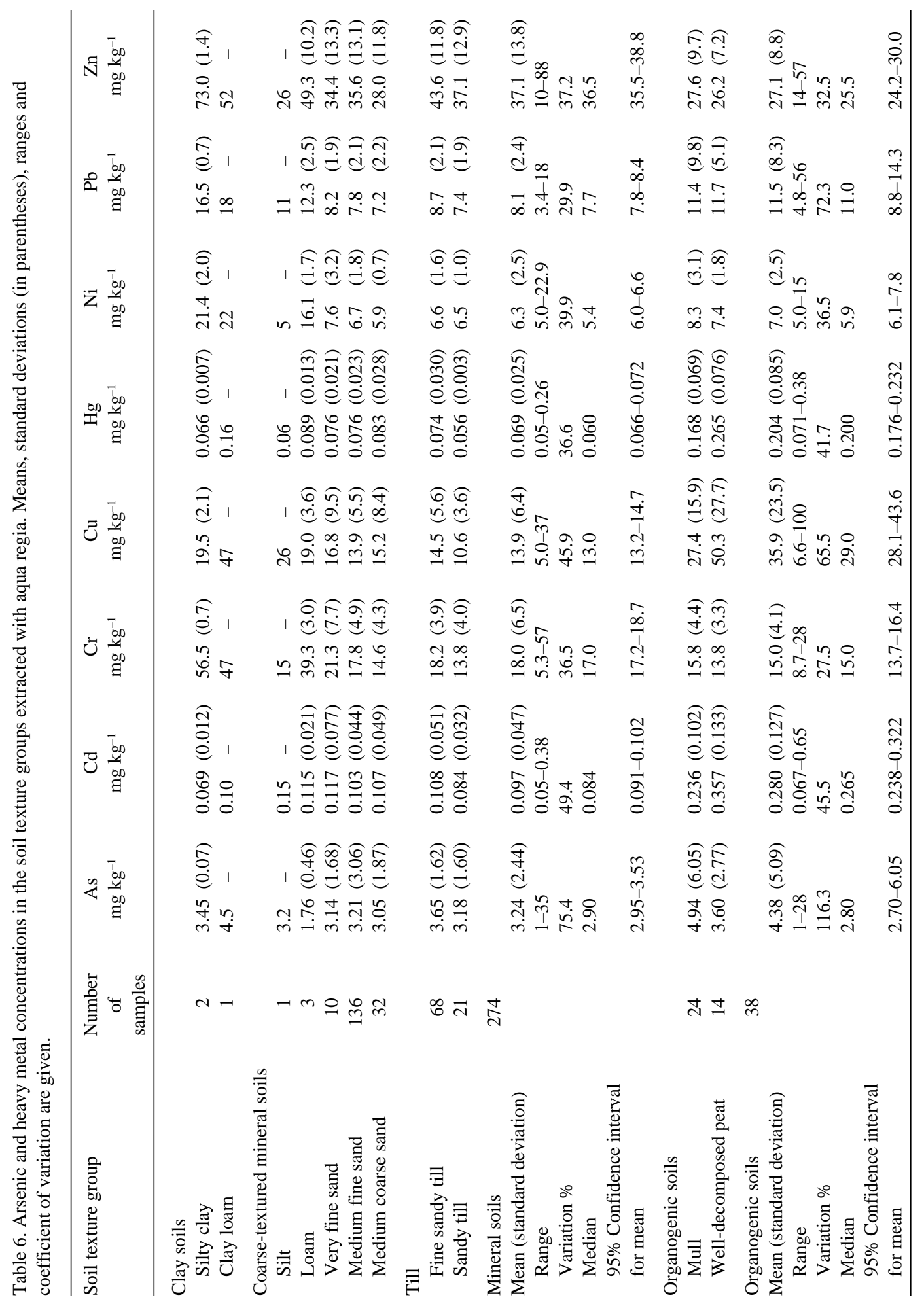


Vol. 11 (2002): 285-300.

Table 7. Arsenic and heavy metal percentiles of the mineral and organogenic soils.

\begin{tabular}{|c|c|c|c|c|c|c|c|c|c|c|}
\hline \multirow[t]{3}{*}{ Element } & \multicolumn{10}{|c|}{ Analysis values expressed as $\mathrm{mg} \mathrm{kg}^{-1}$} \\
\hline & \multicolumn{5}{|c|}{ Mineral soils } & \multicolumn{5}{|c|}{ Organogenic soils } \\
\hline & 5 & 10 & 25 & 50 & 75 & 5 & 10 & 25 & 50 & 75 \\
\hline Arsenic & 1.30 & 1.50 & 2.20 & 2.90 & 3.80 & 1.00 & 1.38 & 2.20 & 2.80 & 4.20 \\
\hline Cadmium & 0.050 & 0.050 & 0.062 & 0.084 & 0.120 & 0.098 & 0.129 & 0.180 & 0.265 & 0.381 \\
\hline Chromium & 9.5 & 12.0 & 14.0 & 17.0 & 20.3 & 8.8 & 9.2 & 12.0 & 15.0 & 17.0 \\
\hline Copper & 5.1 & 6.6 & 9.1 & 13.0 & 18.0 & 11.7 & 15.8 & 20.0 & 29.0 & 43.3 \\
\hline Mercury & 0.050 & 0.050 & 0.050 & 0.060 & 0.078 & 0.080 & 0.089 & 0.128 & 0.200 & 0.270 \\
\hline Nickel & 5.0 & 5.0 & 5.0 & 5.4 & 6.6 & 5.0 & 5.0 & 5.0 & 5.9 & 8.2 \\
\hline Lead & 5.0 & 5.1 & 6.4 & 7.7 & 9.6 & 4.8 & 5.5 & 7.4 & 11.0 & 13.3 \\
\hline Zinc & 17.0 & 20.0 & 26.0 & 36.5 & 46.0 & 16.9 & 18.9 & 21.0 & 25.5 & 29.3 \\
\hline
\end{tabular}

were problematic from the analytical and statistical viewpoint but, on the other hand, indicated that many soils and fields in the province of South Savo contained only very low levels of hazardous elements (Table 6). This phenomenon caused the high clustering especially for cadmium, mercury, nickel and lead in the low percentiles (Table 7). In the organogenic soil group a high proportion of the nickel results fell below the limit of quantification (Table 5) and caused the high clustering in the low percentiles (Table 7).

The concentrations of the various elements were also calculated in units $\mathrm{mg}^{-1}$ (Table 8). The procedure did not markedly change the results for the mineral soils. However, the number of extremes decreased for all elements except nickel and zinc (Table 9). In the organogenic soil group the procedure increased the number of extremes in the case of cadmium and chromium (Table 9).

All the recorded extremes were high extremes. In the mineral soil group the proportion of extremes was $8 \%$ for nickel, $5 \%$ for arsenic, mercury and chromium, $4 \%$ for cadmium, and $2 \%$ or lower for the other elements. Only in the case of arsenic, chromium, mercury and nickel did these extremes cause any pronounced skewness. In the organogenic soil group the high extremes caused noticeable skewness only for arsenic and lead (Table 7). The difference in skewness between the mineral and organogenic soil groups seemed to be restricted to the large number of low values in the mineral soil group excluding copper, lead and zinc (Table 7).

The results were in good agreement with those of Tarvainen and Kuusisto (1999), who reported the median values of arsenic and heavy metal concentrations in arable clay, till and biogenic topsoils in Finland. A mean of $0.15 \mathrm{mg} \mathrm{l}^{-1}$ was reported for the cadmium concentration by Sippola and Mäkelä-Kurtto (1986) for soils in Mikkeli Province (South Savo). Yläranta (1996) reported slightly higher cadmium concentrations: $0.56 \mathrm{mg} \mathrm{kg}^{-1}$ for clay soil, $0.19-0.26 \mathrm{mg} \mathrm{kg}^{-1}$ for coarse-textured mineral soils, and higher values in the vicinity of a smelter $(\mathrm{Cd} 0.21-0.79 \mathrm{mg}$ $\mathrm{kg}^{-1}$ ). Mäkelä-Kurtto and Sippola (1986) reported slightly lower values for the mercury concentration in Finnish agricultural soils than those for this study: the mean for clay soils varied between 0.047 and $0.051 \mathrm{mg} \mathrm{kg}^{-1}$ and of coarsetextured mineral soils between 0.046 and 0.051 $\mathrm{mg} \mathrm{kg}^{-1}$. For till soils the value was $0.049 \mathrm{mg}$ $\mathrm{kg}^{-1}$, for mull soils $0.103 \mathrm{mg} \mathrm{kg}^{-1}$, for Carex peat $0.134 \mathrm{mg} \mathrm{kg}^{-1}$ and for Sphagnum peat $0.060 \mathrm{mg}$ $\mathrm{kg}^{-1}$. The means for the lead concentrations in the Finnish soils were: clay soils $12.9 \mathrm{mg} \mathrm{l}^{-1}$, coarse-textured mineral soils $8.1 \mathrm{mg} \mathrm{l}^{-1}$ and organic soils $5.4 \mathrm{mg} \mathrm{l}^{-1}$ (Sippola and Mäkelä-Kurtto 1993), which corresponded relatively well with the values recorded in this study.

Arsenic and heavy metal concentrations in Finnish basal till samples $(<0.06 \mathrm{~mm}$ size frac- 
Mäntylahti, V. \& Laakso, P. Arsenic and heavy metal concentrations in agricultural soils

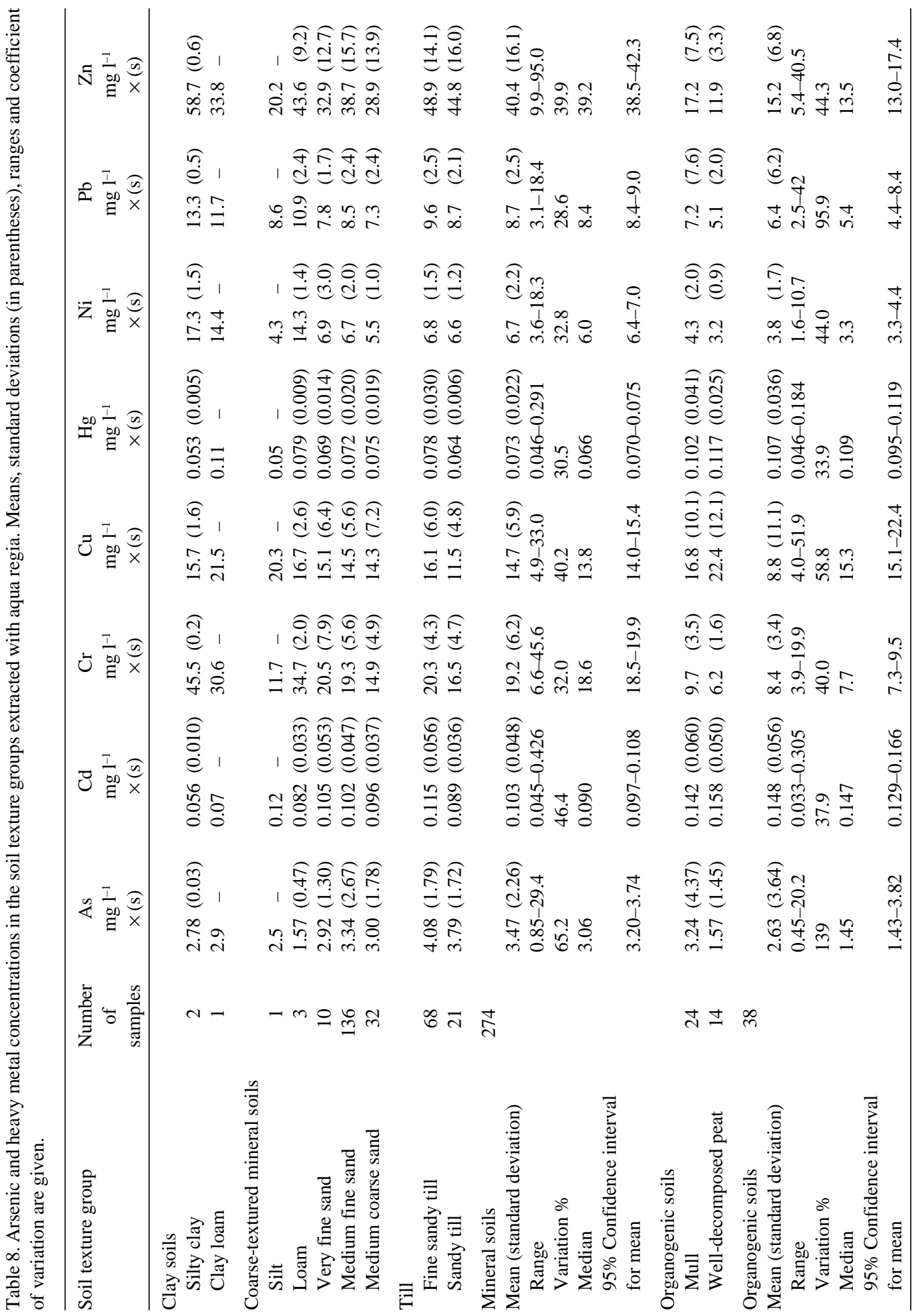


Vol. 11 (2002): 285-300.

Table 9. The number of extreme values for arsenic and heavy metals. The limit value from which the values were grouped into the extremes is given in parentheses.

\begin{tabular}{|c|c|c|c|c|}
\hline \multirow[t]{2}{*}{ Element } & \multicolumn{2}{|c|}{$\begin{array}{l}\text { Analysis values expressed as } \\
\qquad \mathrm{mg} \mathrm{kg}^{-1}\end{array}$} & \multicolumn{2}{|c|}{$\begin{array}{l}\text { Analysis values expressed as } \\
\qquad \mathrm{mg} \mathrm{l}^{-1}\end{array}$} \\
\hline & $\begin{array}{l}\text { Mineral } \\
\text { soils }\end{array}$ & $\begin{array}{l}\text { Org. } \\
\text { soils }\end{array}$ & $\begin{array}{l}\text { Mineral } \\
\text { soils }\end{array}$ & $\begin{array}{l}\text { Org. } \\
\text { soils }\end{array}$ \\
\hline Arsenic & $\begin{array}{c}13 \\
\left(>6.5 \mathrm{mg} \mathrm{kg}^{-1}\right)\end{array}$ & $\begin{array}{c}6 \\
\left(>7.1 \mathrm{mg} \mathrm{kg}^{-1}\right)\end{array}$ & $\begin{array}{c}12 \\
\left(>7.5 \mathrm{mg} \mathrm{l}^{-1}\right)\end{array}$ & $\begin{array}{c}6 \\
\left(>5.4 \mathrm{mg} \mathrm{l}^{-1}\right)\end{array}$ \\
\hline Cadmium & $\begin{array}{c}10 \\
\left(>0.210 \mathrm{mg} \mathrm{kg}^{-1}\right)\end{array}$ & - & $\begin{array}{c}5 \\
\left(>0.218 \mathrm{mg} \mathrm{l}^{-1}\right)\end{array}$ & $\begin{array}{c}2 \\
\left(>0.27 \mathrm{mg} \mathrm{l}^{-1}\right)\end{array}$ \\
\hline Chromium & $\begin{array}{c}13 \\
\left(>29 \mathrm{mg} \mathrm{kg}^{-1}\right)\end{array}$ & $\begin{array}{c}2 \\
\left(>25 \mathrm{mg} \mathrm{kg}^{-1}\right)\end{array}$ & $\begin{array}{c}8 \\
\left(>34 \mathrm{mg} \mathrm{l}^{-1}\right)\end{array}$ & $\begin{array}{c}3 \\
\left(>14.8 \mathrm{mg} \mathrm{l}^{-1}\right)\end{array}$ \\
\hline Copper & $\begin{array}{c}5 \\
\left(>32 \mathrm{mg} \mathrm{kg}^{-1}\right)\end{array}$ & $\begin{array}{c}4 \\
\left(>85 \mathrm{mg} \mathrm{kg}^{-1}\right)\end{array}$ & $\begin{array}{c}2 \\
\left(>33 \mathrm{mg} \mathrm{l}^{-1}\right)\end{array}$ & $\begin{array}{c}2 \\
\left(>47 \mathrm{mg} \mathrm{l}^{-1}\right)\end{array}$ \\
\hline Mercury & 15 & - & 8 & - \\
\hline Nickel & $\begin{array}{c}\left(>0.120 \mathrm{mg} \mathrm{kg}^{-1}\right) \\
23 \\
\left(>9.2 \mathrm{mg} \mathrm{kg}^{-1}\right)\end{array}$ & $\begin{array}{c}3 \\
\left(>13 \mathrm{mg} \mathrm{kg}^{-1}\right)\end{array}$ & $\begin{array}{c}\left(>0.121 \mathrm{mg} \mathrm{l}^{-1}\right) \\
27 \\
\left(>9.7 \mathrm{mg} \mathrm{l}^{-1}\right)\end{array}$ & $\begin{array}{c}2 \\
\left(>7.2 \mathrm{mg} \mathrm{l}^{-1}\right)\end{array}$ \\
\hline Lead & $\begin{array}{c}5 \\
\left(>15 \mathrm{mg} \mathrm{kg}^{-1}\right)\end{array}$ & $\begin{array}{c}2 \\
\left(>23 \mathrm{mg} \mathrm{kg}^{-1}\right)\end{array}$ & $\begin{array}{c}3 \\
\left(>15.6 \mathrm{mg} \mathrm{l}^{-1}\right)\end{array}$ & $\begin{array}{c}2 \\
\left(>9.9 \mathrm{mg} \mathrm{l}^{-1}\right)\end{array}$ \\
\hline Zinc & $\begin{array}{c}3 \\
\left(>78 \mathrm{mg} \mathrm{kg}^{-1}\right)\end{array}$ & $\begin{array}{c}3 \\
\left(>42 \mathrm{mg} \mathrm{kg}^{-1}\right)\end{array}$ & $\begin{array}{c}4 \\
\left(>85 \mathrm{mg} \mathrm{l}^{-1}\right)\end{array}$ & $\begin{array}{c}2 \\
\left(>29 \mathrm{mg} \mathrm{l}^{-1}\right)\end{array}$ \\
\hline
\end{tabular}

tion) were reported by Nenonen and Nikkarinen (1995) and Tarvainen and Kallio (1999). According to their results, the median for arsenic concentration was lower than the limit of quantification $\left(2.0 \mathrm{mg} \mathrm{kg}^{-1}\right)$. Furthermore, the median for cadmium concentration also fell below the limit of quantification $\left(0.5 \mathrm{mg} \mathrm{kg}^{-1}\right)$. The medians for the other heavy metal concentrations were: $\mathrm{Cr} 30.5 \mathrm{mg} \mathrm{kg}^{-1}$, Cu $15.7 \mathrm{mg} \mathrm{kg}^{-1}$, Ni 14.1 $\mathrm{mg} \mathrm{kg}{ }^{-1}, \mathrm{~Pb} 10.6 \mathrm{mg} \mathrm{kg}^{-1}$ and $\mathrm{Zn} 24.6 \mathrm{mg} \mathrm{kg}^{-1}$. The concentrations of chromium and nickel were slightly higher than those obtained in this study.

Arsenic and heavy metal concentrations in the Nordic countries have been reported by Esser (1996) in Norway, Jeng and Bergseth (1992) in Finland, Norway and Sweden, and Eriksson et al. (1997) in Sweden. The medians and means presented in those reports are in good agreement with these. However, the arsenic and heavy metal concentrations were essentially higher in soils that developed on alum shales and in till soils overlying alum shale bedrock (Jeng and Bergseth 1992).

Arsenic and heavy metal concentrations have been investigated extensively in countries including Austria, Germany, the Netherlands, Poland and Scotland (Aichberger et al. 1982, Hoffmann et al. 1982, van Driel and Smilde 1982, Berrow and Reaves 1984, Grupe 1989, Chlopecka et al. 1996, Hornburg and Lüer 1999). The values reported were characterized by substantial variation and much higher values for skewness (e.g. Berrow and Reaves 1984) than those reported in this study.

The arsenic and heavy metal concentrations in soils of South Savo province were at approximately the same level as those in other Finnish soils. The concentrations were also relatively similar to those reported in other Nordic studies and slightly lower than those for Central Europe (e.g. Austria, Germany, the Netherlands, Poland and Scotland). 
Mäntylahti, V.\& Laakso, P. Arsenic and heavy metal concentrations in agricultural soils

\section{Element enrichment in mineral or organogenic soils}

The median zinc concentration in the organogenic soil group was lower than that in the mineral soil group. Analogously the medians of the arsenic, chromium and nickel concentrations were at approximately the same level in both the mineral and organogenic soil groups, while those of cadmium, copper, mercury and lead were higher in the organogenic soil group than in the mineral soil group (Table 6). The differences between the mineral and organogenic soil groups would be larger if the values below the limit of quantification were replaced by the actual concentrations. Accordingly, the medians for cadmium, copper, mercury and nickel concentrations in the organogenic soil group were higher than those in the mineral soil group. The cadmium, copper and mercury concentrations (medians) in the organogenic soil group were nearly three times higher than those of the other elements (Table 6). This finding is in good agreement with the concept of element enrichment. Van Driel and Smilde (1982) reported the enrichment of cadmium, lead and to some extent also arsenic in fen-peat soils compared with mineral soils, but the results of Tarvainen and Kuusisto (1999) did not reveal a corresponding trend. The enrichment of elements (e.g. arsenic, cadmium, and lead) in topsoil (Aichberger et al. 1982, Kabata-Pendias and Adriano 1995) and the use of agrochemicals (e.g. Mäkelä-Kurtto 1998) explained the higher concentrations of cadmium, copper and mercury in organogenic soils because the chemicals were spread in units of grams (or kilograms) per hectare and the results of the soil analysis were calculated in units of $\mathrm{mg} \mathrm{kg}^{-1}$ soil.

\section{Typical concentrations of trace elements in South Savo}

Element concentrations are frequently classified on the basis of the typical background concen- trations in uncontaminated soils (e.g. Hoffmann et al. 1982, van Driel and Smilde 1982, Berrow and Reaves 1984, Smit 1997, Terelak et al. 1997). However, the background values vary, and many different classes have been presented for different soil groups, $\mathrm{pH}$ levels, clay contents and organic matter contents (e.g. Kabata-Pendias and Adriano 1995, Smit 1997, Terelak et al. 1997, Ympäristöministeriö 2000).

The Finnish Ministry of the Environment (Ympäristöministeriö 2000) proposed a draft for the normative and target values for heavy metals in Finnish soils. The adjusted target values depend on the clay content (particles $<0.002$ $\mathrm{mm}$ ) and organic matter content of the soil. The formula is based on Dutch target values (Smit 1997) but relies on smaller constants. The results from this study were compared with the target values (Table 10). All the average concentrations of elements in the mineral soil group fell below the normative value, but the mercury concentration of the organogenic soils exceeded the normative value. Thus the results included values that exceeded the target values. Detailed analysis of the results indicated that the normative value $\left(10 \mathrm{mg} \mathrm{kg}^{-1}\right)$ of arsenic was exceeded in both the mineral soil group ( 2 samples) and the organogenic soil group (3 samples). The adjusted target value, but not the limit value (As $60 \mathrm{mg} \mathrm{kg}^{-1}$ ) was exceeded in 26 mineral soil samples and one organogenic soil sample. Moreover, the normative value for the cadmium concentration $\left(\mathrm{Cd} 0.5 \mathrm{mg} \mathrm{kg}^{-1}\right)$ was exceeded in one organogenic soil sample. The adjusted target value, but not the limit value ( $\left.\mathrm{Cd} 10 \mathrm{mg} \mathrm{kg}^{-1}\right)$, was also exceeded in the sample. The normative value for mercury ( $\mathrm{Hg} 0.2 \mathrm{mg} \mathrm{kg}^{-1}$ ), as well as the adjusted target value was exceeded in one mineral soil sample, but the limit value ( $\mathrm{Hg} 5 \mathrm{mg}$ $\mathrm{kg}^{-1}$ ) was not. In the organogenic soil group there were 18 samples for which the normative value was exceeded. The results from eight samples exceeded the adjusted target value but not the limit value. Nenonen and Nikkarinen (1995) analyzed the $<0.06 \mathrm{~mm}$ fraction of the subsoil in Finnish glacial till and reported concentrations of arsenic, chromium and nickel that exceeded 
Vol. 11 (2002): 285-300.

Table 10. Limit values for arsenic and heavy metals compared with published values and those in the Draft of the Finnish Ministry of the Environment.

\begin{tabular}{|c|c|c|c|c|c|c|c|c|c|}
\hline \multirow[t]{3}{*}{ Element } & \multicolumn{4}{|c|}{$\begin{array}{l}\text { This study } \\
\text { "Limit value for Clean Soil" } \\
\text { Mean + standard deviation }\end{array}$} & \multirow{3}{*}{$\begin{array}{l}\text { Viljavuus- } \\
\text { palvelu } \\
\text { Oy } 2000 \\
\\
\text { Target } \\
\text { value for } \\
\text { Clean Soil } \\
\text { mg kg-1 }^{-1}\end{array}$} & \multicolumn{4}{|c|}{$\begin{array}{c}\text { The Finnish Ministry of the Environment, } \\
\text { Draft 24.3.2000 }\end{array}$} \\
\hline & \multicolumn{2}{|c|}{ Mineral soils } & \multicolumn{2}{|c|}{ Organogenic soils } & & \multirow{2}{*}{$\begin{array}{l}\text { Norma- } \\
\text { tive } \\
\text { value } \\
\mathrm{mg} \mathrm{kg}^{-1}\end{array}$} & \multirow{2}{*}{$\begin{array}{c}\text { Adjusted target } \\
\text { value } \mathrm{mg} \mathrm{kg}^{-1} \\
(\mathrm{~s}=\text { clay content } \% \\
\mathrm{o}=\text { organic matter } \\
\text { content } \%)\end{array}$} & \multirow{2}{*}{$\begin{array}{l}\text { Based on the } \\
\text { formula(preced- } \\
\text { ing column), } \\
\text { All soils } \\
\mathrm{mg} \mathrm{kg}^{-1}\end{array}$} & \multirow{2}{*}{$\begin{array}{l}\text { Limit } \\
\text { value } \\
\mathrm{mg} \mathrm{kg}^{-1}\end{array}$} \\
\hline & $\mathrm{mg} \mathrm{kg}^{-1}$ & $\mathrm{mg} \mathrm{l}^{-1}$ & $\mathrm{mg} \mathrm{kg}^{-1}$ & $\mathrm{mg} \mathrm{1}^{-1}$ & & & & & \\
\hline Arsenic & 5.68 & 5.73 & 9.47 & 6.27 & - & 10 & $2+0.4(s+o)$ & 7.82 (5.18) & 60 \\
\hline Cadmium & 0.144 & 0.151 & 0.407 & 0.204 & 0.30 & 0.5 & $0.1+0.007(\mathrm{~s}+30)$ & $0.352(0.262)$ & 10 \\
\hline Chromium & 24.5 & 25.4 & 19.1 & 11.8 & 70 & 100 & $30+2 s$ & $37.6(9.3)$ & 400 \\
\hline Copper & 20.3 & 20.6 & 59.4 & 29.9 & 35 & 100 & $15+0.6(\mathrm{~s}+\mathrm{o})$ & $23.7(7.8)$ & 400 \\
\hline Mercury & 0.094 & 0.095 & 0.289 & 0.143 & 0.10 & 0.2 & $0.1+0.0017(2 \mathrm{~s}+\mathrm{o})$ & $0.131 \quad(0.025)$ & 5 \\
\hline Nickel & 8.8 & 8.9 & 9.5 & 5.5 & 35 & 60 & $15+s$ & 18.8 & 300 \\
\hline Lead & 10.5 & 11.2 & 19.8 & 12.6 & 20 & 60 & $10+(s+o)$ & $24.6(13.0)$ & 300 \\
\hline Zinc & 50.9 & 56.5 & 35.9 & 22.0 & 110 & 150 & $10+1.5(2 \mathrm{~s}+\mathrm{o})$ & $37.5(22.4)$ & 700 \\
\hline
\end{tabular}

the normative and limit values issued by the Ministry of the Environment. Tarvainen (1996) estimated the element concentrations in the coarse fraction $(<2 \mathrm{~mm})$ of Finnish till and reported that the natural concentrations of chromium, copper, nickel, and zinc exceeded the normative and limit values.

The results of the study indicated that the average concentrations of all the elements in the mineral soil group were smaller than the proposed limit for "Clean Soil". However, in the organogenic soils the average concentrations of cadmium and mercury exceeded the proposed level for "Clean Soil". The conversion of the results into units of $\mathrm{mg} \mathrm{l}^{-1}$ reduced the problem, but did not eliminate it for mercury. On the other hand, the results indicated that the cadmium and mercury concentrations in the soils of South Savo province were at a slightly higher level than those reported in other Finnish studies.

\section{Conclusions}

In most cases the concentrations of arsenic and heavy metals were at the same level as those re- ported in other Nordic studies. In most cases the concentrations were lower and the ranges were narrower than those of soils in Austria, Germany, the Netherlands, Poland and Scotland. However, some special features were found for cadmium and mercury. The mercury concentration of the soils in South Savo province was relatively higher than for other elements when compared with results obtained previously in Finland. The group of organogenic soils also had relatively higher mercury concentrations than those reported in other Finnish studies. Expressing the values on the basis of the clay content and the organic matter content did not eliminate all the values that exceeded the normative values, but it did decrease the number of samples for which the value was exceeded.

The criteria developed in this study to determine the limit values for a "Clean Soil" were in good agreement with those proposed by Soil Analysis Service Ltd (Viljavuuspalvelu 2000). The method used to determine the target values was identical in this study and in that carried out by Soil Analysis Service Ltd. The target values are presented with some modifications in Table 11 .

The results indicated that there are many 
Mäntylahti, V. \& Laakso, P. Arsenic and heavy metal concentrations in agricultural soils

Table 11. The draft of the target values for "Clean Soil".

\begin{tabular}{lcc}
\hline Element & $\begin{array}{c}\text { Mineral soils } \\
\mathrm{mg} \mathrm{kg}^{-1}\end{array}$ & $\begin{array}{c}\text { Organogenic soils } \\
\mathrm{mg} \mathrm{l}^{-1}\end{array}$ \\
\hline Arsenic & 10 & 10 \\
Cadmium & 0.30 & 0.30 \\
Chromium & 70 & 70 \\
Copper & 35 & 35 \\
Mercury & 0.10 & 0.15 \\
Nickel & 35 & 25 \\
Lead & 20 & 20 \\
Zinc & 100 & 100 \\
\hline
\end{tabular}

fields in South Savo province that contain only very small amounts of arsenic and heavy metals. These fields could be used for crop production and provided with the "Clean Soil" hallmark. The same classification could be used for all soils with low trace element concentrations.

Acknowledgements. We thank the Mikkeli Rural Advisory Centre and Vapo Oy for their excellent cooperation during the study. The work was funded by the European Regional Development Fund (ERDF) Objective 1.

\section{References}

Aaltonen, V.T., Aarnio, B., Hyyppä, E., Kaitera, P., Keso, L., Kivinen, E., Kokkonen, P., Kotilainen M.J., Sauramo, M., Tuorila, P. \& Vuorinen, J. 1949. Summary: A critical review of soil terminology and soil classification in Finland in the year 1949. Journal of the Scientific Agricultural Society of Finland 21: 37-66.

Aichberger, K., Bachler, W. \& Pichler, H. 1982. Schwermetalle in Böden Oberösterreichs und deren Verteilung im Bodenprofil. Landwirtschaftliche Forschung, Sonderheft 35: 350-362.

ASTM 1997. Standard practice for using significant digits in test data to determine conformance with specifications. Annual book of ASTM standards. Volume 14.02, E29: 19-22.

Berrow, M.L. \& Reaves, G.A. 1984. Background levels of trace elements in soils. In: Environmental contamination United Nations environment programme. $\mathrm{p}$. 333-340.

Chlopecka, A., Bacon, J.R., Wilson, M.J. \& Kay, J. 1996. Forms of cadmium, lead, and zinc in contaminated soils from southwest Poland. Journal of Environmental Quality 25: 69-79.

Directive 86/278/EEC. Council directive on the use of sewage sludge on agricultural land. Official Journal L181: 6-12.

Van Driel, W. \& Smilde, K.W. 1982. Heavy-metal concentrations of Dutch arable soils. Landwirtschaftliche Forschung, Sonderheft 35: 305-313.

Elonen, P. 1971. Particle-size analysis of soil. Acta Agralia Fennica 122: 1-122.

Eriksson, J., Andersson, A. \& Andersson, R. 1997. Tillståndet i svensk åkermark. Naturvårdverket, Rapport 4778. p. 1-59.

Esser, K. 1996. Reference concentrations for heavy metals in mineral soils, oat, and orchard grass (Dactylis glomerata) from three agricultural regions in Norway. Water, Air, and Soil Pollution 89: 375-397.

Graham, E.R. 1948. Determination of soil organic matter by means of a photoelectric colorimeter. Soil Science 65: $181-183$.
Grupe, M. 1989. Schwermetallgehalte in Böden in Abhängigkeit vom Ausgangssubstrat. Mitteilungen der Deutschen Bodenkundlichen Gesellschaft 59: 895896.

Hoffmann, G.G., Schweiger, P., Scholl, W. \& Schmied R. 1982. Grundbelastung der Böden von Baden-Würtemberg mit Schwermetallen. Landwirtschaftliche Forschung, Sonderheft 35: 324-337.

Hornburg, V. \& Lüer, B. 1999. Vergleich zwischen Totalund königswasserextrahierbaren Elementhalten in naturlichen Böden und Sedimenten. Zeitschrift für Pflanzenernährung und Bodenkunde 162: 131-137.

ISO 11047. Soil quality - Determination of cadmium, chromium, cobalt, copper, lead, manganese, nickel and zinc in aqua regia extracts of soil - Flame and electrothermal atomic absorption spectrometric methods. International Organization for Standardization 1998.

ISO 11464. Soil quality - Pretreatment of samples for physico-chemical analyses. International Organization for Standardization 1994.

ISO 11466. Soil quality - Extraction of trace elements soluble in aqua regia. International Organization for Standardization 1995.

Jeng, A.S. \& Bergseth, H. 1992. Chemical and mineralogical properties of Norwegian alum shale soils, with special emphasis on heavy metal concentration and availability. Acta Agriculturae Scandinavica. Section $B$, Soil and Plant Science 42: 88-93.

Kabata-Pendias, A. \& Adriano, D.C. 1995. Trace metals. In: Rechcigl, J.E. (ed.). Soil amendments and environmental quality. Boca Raton USA. p. 139-167.

Kähäri, J, Mäntylahti, V. \& Rannikko, M. 1987. Suomen peltojen viljavuus 1981-1985. Summary: Soil fertility of Finnish cultivated soils in 1981-1985. Helsinki. Viljavuuspalvelu Oy. $105 \mathrm{p}$.

Lahdenperä, A.-M., Tamminen, P. \& Tarvainen, T. 2001. Relationships between geochemistry of basal till and chemistry of surface soil at forested sites in Finland. Applied Geochemistry 16: 123-136.

Lakanen, E. \& Erviö, R. 1971. A comparison of eight 
Vol. 11 (2002): 285-300.

extractants for the determination of plant available micronutrients in soils. Acta Agralia Fennica 122: 223-232.

Mäkelä-Kurtto, R. 1998. Raskasmetalliriskit ja niiden hallinta maataloudessa. In: Salo, R. (ed.). Sata vuotta maataloustutkimusta: Mihin tutkimus johtaa tuotantoa? MTT:n julkaisuja. Sarja A 38. p. 57-64.

Mäkelä-Kurtto, R. \& Sippola, J. 1986. Viljelysmaittemme elohopeapitoisuus. Koetoiminta ja käytäntö 43: 9.

Mohammadi, O., Yli-Halla, M. \& Mäntylahti, V. 1991. Determination of plant-available manganese from soils by acid ammonium acetate-EDTA extraction. Journal of Agricultural Science in Finland 63: 85-92.

Nenonen, K. \& Nikkarinen, M. 1995. Natural arsenic, chromium and nickel concentrations in Finnish soil. Is Finnish soil naturally clean? In: Saski, E. \& Saarinen, T. (eds.). Proceedings of the second Finnish conference of environmental sciences, Helsinki, 16-18 November 1995. Microbiological Publications 43: 304-310.

Nykänen-Kurki, P., Mäkelä-Kurtto, R., Mäkinen-Aakula, M., Tontti, T. \& Mäntylahti, V. 2001. Mikkelin kaupungin puhdistamolietteen käyttömahdollisuus maataloudessa. Abstract: Agricultural use of sludge from sewage treatment plant of the City of Mikkeli. MTT publications. Series $A$ 95. Jokioinen: MTT. $38 p+1$ app.

Salminen, R. 1995. (ed.). Alueellinen geokemiallinen kartoitus Suomessa vuosina 1982-1994. English summary: Regional geochemical mapping in Finland in 1982-1994. Geological Survey of Finland, Report of Investigation 130. $44 \mathrm{p}+24$ app.

Salminen, R. \& Lampio, E. 1995. Tulokset. Alueellinen geokemiallinen kartoitus Suomessa vuosina 19821994. Geologian tutkimuskeskus, Tutkimusraportti 130. p. 41-42.

Sillanpää, M. 1982. Micronutrients and the nutrient status of soils: A global study. FAO Soils bulletin 48 . Rome. 444 p.

Sippola, J. \& Mäkelä-Kurtto, R. 1986. Cadmium in cultivated Finnish soils. Annales Agriculturae Fenniae 25: 255-263.

Sippola, J. \& Mäkelä-Kurtto, R. 1993. Decreasing lead levels in cultivated soils in Finland. International Journal of Environmental Analytical Chemistry 51:
201-203.

Smit, H. 1997. Contaminated soils. Proceedings of Colloquium 3. International Conference on the Biochemistry of Trace Elements, Paris, May 15-19, 1995. INRA 1997. $6 \mathrm{p}$.

Tamminen, P. \& Starr, M. 1990. A survey of forest soil properties related to soil acidification in southern Finland. In: Kauppi, P. et al. (eds.). Acidification in Finland. Berlin: Springer-Verlag. p. 235-251.

Tarvainen, T. 1995. The geochemical correlation between coarse and fine fractions of till in southern Finland. Journal of Geochemical Exploration 54: 187-198.

Tarvainen, T. 1996. Environmental applications of geochemical databases in Finland. Espoo: Geological Survey of Finland. 75 p.

Tarvainen, T. \& Kallio, E. 1999. Baselines of certain bioavailable and total heavy metal concentrations in Finland. Water and Environmental Engineering. Report 9: 220-223.

Tarvainen, T. \& Kuusisto, E. 1999. Baltic soil survey: Finnish results. Geological Survey of Finland, Special Paper 27. p. 69-77.

Tarvainen, T., Lahermo, P. \& Mannio, J. 1997. Sources of trace metals in streams and headwater lakes in Finland. Water, Air, and Soil Pollution 94: 1-32.

Terelak, H., Stuczynski, T. \& Piotrowska, M. 1997. Heavy metals in agricultural soils in Poland. Polish Journal of Soil Science 30: 35-42.

Ure, A.M. 1990. Methods of analysis of heavy metals in soils. In: Alloway, B.J. (ed.). Heavy metals in soils. East Kilbride, Scotland. p. 40-80.

Viljavuuspalvelu 2000. Viljavuustutkimuksen tulkinta peltoviljelyssä. Mikkeli. 31 p.

Vuorinen, J. \& Mäkitie, O. 1955. The method of soil testing in use in Finland. Agrogeological Publications 63: $1-44$.

Yläranta, T. 1996. Uptake of heavy metals by plants from airborne deposition and polluted soils. Agricultural Science in Finland 5: 431-447.

Ympäristöministeriö 2000. Ehdotus valtioneuvoston asetukseksi maa-alueen maaperän pilaantuneisuuden selvittämisestä ja puhdistustarpeen arvioinnista. Ympäristöministeriö, Muistio 24.3.2000, Luonnos. $14 \mathrm{p}$. 
Mäntylahti, V. \& Laakso, P. Arsenic and heavy metal concentrations in agricultural soils

\title{
SELOSTUS
}

\section{Etelä-Savon viljelysmaan arseeni- ja raskasmetallipitoisuudet}

\author{
Väinö Mäntylahti ja Pirkko Laakso \\ Viljavuuspalvelu $\mathrm{Oy}$
}

Syksyllä 2000 kerättiin Etelä-Savosta Maaseutukeskus Mikkelin alueelta 23 tilalta 274 näytettä kivennäismaista ja 38 näytettä eloperäisistä maista. Näytteet otettiin tavanomaisilta viljelysmailta, ja niistä määritettiin kuningasveteen uuttuvien arseenin, kromin, kadmiumin, kuparin, elohopean, nikkelin, lyijyn ja sinkin pitoisuudet. Alkuainepitoisuudet laskettiin perinteisesti yksikköinä $\mathrm{mg} / \mathrm{kg}$, mutta myös yksikköinä mg/l, koska maan irtotiheyden oletettiin vaikuttavan tuloksiin.

Alkuainepitoisuuksien mediaanit olivat: As 2,90

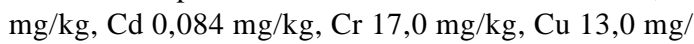

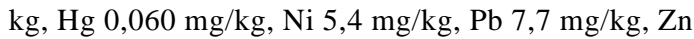
$36,5 \mathrm{mg} / \mathrm{kg}$. Eloperäisillä mailla vastaavat tulokset olivat: As 2,80 mg/kg, Cd 0,265 mg/kg, Cr 15,0 mg/ $\mathrm{kg}, \mathrm{Cu} 29,0 \mathrm{mg} / \mathrm{kg}, \mathrm{Hg} 0,200 \mathrm{mg} / \mathrm{kg}$, Ni $5,9 \mathrm{mg} / \mathrm{kg}$, $\mathrm{Pb} 11,0 \mathrm{mg} / \mathrm{kg}, \mathrm{Zn} 25,5 \mathrm{mg} / \mathrm{kg}$. Kivennäismaiden ja eloperäisten maiden kadmium- ja elohopeapitoisuudet poikkesivat toisistaan. Muutamat arseenin, kadmiumin ja elohopean pitoisuudet ylittivät ns. taustaarvot, mutta eivät saastuneiden maiden raja-arvoja. Useimmissa Etelä-Savon pelloissa oli vain pieniä määriä arseenia ja raskasmetalleja, kun pitoisuuksia verrattiin Suomen, muiden Pohjoismaiden ja KeskiEuroopan viljelysmaihin. Näitä Etelä-Savon peltoja voitaisiin käyttää erikoisviljelyyn varustaen ne Puhdas maa -merkinnällä. 